\title{
Om modern homofobi
}

Borgström, Eva (red) Den moderna homofobin.

Stockholm: Charlie by Kabusa 20I I (2 I I sidor)

Öhrman, Anders Komma ut: berättelser från garderoben.

Stockholm: Natur och Kultur 2006 (245 sidor)

FÖR ETT PAR år sen föreläste den kände tyske medieteoretikern K. i Sthlm, inbjuden av institutionen för litteraturvetenskap vid SU. Enligt en deltagare vid föreläsningen var det hela "fullkomligt obegripligt, inte minst för att $\mathrm{K}$. själv tycktes växla fritt mellan engelska, tyska och grekiska." När institutionens presentatör N. senare efterlyste frågor och synpunkter var det fullkomligt tyst $\mathrm{i}$ salen.

Roligare var den chockartade tystnad som uppstod efter att K.

dristat sig till ett bögskämt. Det hela rörde binära oppositioner och ettor och nollor, och K. stack plötsligt och tämligen omotiverat in en kommentar som antydde att det ju inte var svårt att förstå varför just Foucault hade svårt för sådana par. Det hela illustrerades av en obscen gest, där K. stötte två pekfingrar ("ettor") mot varandra.

$\mathrm{N}$ blev högröd. 
Den här historien, som finns på en blogg på nätet, kan tas som ett exempel på alltför vanlig vardagshomofobi: personer som rimligen borde ha bättre kunskap kan aningslöst offentligt uttrycka sig nedlåtande om homosexuella utan att inse att den grupp man talar till också inkluderar personer som drabbas av deras skämt. I boken Den moderna homofobin berättar Margareta Lindholm en liknande historia från en annan vetenskaplig institution:

En [...] man på arbetsplatsen [U] ansåg att jag behövde få kuk. Få känna på kuk. Det gjorde jag nog alltför sällan i hans tycke, eftersom jag var som jag var.

Detta framförde han vid minst två tillfällen. Ena tillfället i korridoren. Jag stod inne i kafferummet, dold för honom och han trodde nog att jag inte hörde. Att andra hörde var inget problem. Tvärtom.

Vid det andra tillfället befann han sig i korridoren strax utanför mitt arbetsrum. Dörren var stängd. Han stod utanför och pratade med en annan man om min person. Jag smög fram till dörren och slet upp den. U. studsade bakåt och halvsprang bortåt i korridoren. Kommen en bit på väg, fann han sig och tyckte det tarvades en förklaring. Då ropade han: ”Jag trodde inte att du var där!” (45-6.)

Eva Borgström, som också är redaktör för Den moderna homofobin, berättar i sin artikel ännu ett exempel på den ännu kvarvarande homofobin inom den akademiska forskningen. Hon tar som exempel två biografier över drottning Kristina, en icke genusnormativ regent som sedan mycket länge bland äldre historiker tolkats som kvinnoälskande. Hon har själv tidigare behandlat frågan i en längre artikel, "Drottning Kristina och hermafroditens tankefigur" (lambda nordica I/I998). Kanske just som en protest har två högt meriterade histo- 
riker, Svenska Akademiens ständige sekreterare Peter Englund och historieprofessorn Marie-Louise Rodén, i var sin Kristina-biografi 2006 och 2008 ivrigt strävat efter att heterosexualisera drottningen. De mycket kärleksfulla breven till hovdamen Ebba Sparre, "sängvärmaren”, skulle bero på att Kristina var nyförälskad i en man! Sådana uttryck av missriktad "äreräddning” av kända personer är tyvärr inte unika bland nutida historiker eller litteraturvetare. I Svenska Akademiens officiella minnesskrift över Gustav III I986 hävdade historieprofessorn och akademiledamoten Erik Lönnroth att kungen endast hade heterosexuella intressen, trots att dennes närmaste familj, som modern och svägerskan Hedvig Elisabeth Charlotta, klart dokumenterat en diametralt annan uppfattning.

Boken innehåller $\mathrm{I} 4$ fristående essäer av olika författare, förutom ett övergripande förord av redaktören Eva Borgström. Bland andra medverkar prästen Lars Gårdfeldt med en personlig skildring av Svenska kyrkans långvariga motstånd mot officiell välsignelse av homosexuella parförhållanden, senare dock godkänt om det skedde utan vittnen och inte gav intryck av att sådana förhållanden stöddes av kyrkan. Med undantag för ett antal fundamentalistiska präster (som f.ö. inte heller brukar acceptera kvinnliga präster) har Svenska kyrkan glädjande nog idag en helt annan mening. Fanny Ambjörnsson intervjuar unga och äldre om deras syn på öppenheten, och konstaterar förändrade attityder som kan skönjas hos en yngre generation queeridentifierade personer. Det handlar också om en osäkerhet kring exakt vad det är som ska bekännas, man vill inte identifiera sig med de fasta identitetspositioner som samhället erbjuder.

Andy Candy skildrar transsexuellas speciella situation. Transfobin skiljer sig markant från homofobin - den är inte heller lika väldokumenterad och utforskad och enbart ett fåtal fall av transfobi 
har lett till en fällande dom. Människor som avviker från accepterade och normerande könsroller drabbas, oavsett sexuell läggning och biologiskt kön - inte bara transpersoner.

Det är kanske ofrånkomligt att vi känner igen många av författarna och deras berättelser. Sune Innala beskriver sitt forskningsområde "Homofobins struktur och konsekvenser", och Arne Nilsson berättar om livet ombord på Amerikabåtarna och tystnaden kring denna speciella homosubkultur förr - och än idag.

Eva Tiby tar ännu en gång upp ämnet hatbrott och kvardröjande politisk homofobi, särskilt aktuella ämnen just nu efter den våg av självmord bland mobbade homosexuella skolungdomar som uppmärksammats i USA: de unga och skolan som en arena för heteronormativitet. Internationell forskning har visat att förhållandena är lika i alla undersökta länder i världen. I Amerika har de ungas svåra situation lett till en videokampanj under temat "It will get better!"; ett tema som tyvärr (ganska homofoba) Rädda Barnen har exploaterat i Sverige under rubriken "Det blir bättre" tillsammans med den kommersiella kanalen $\mathrm{TV}_{3}$, men utan begreppets ursprungliga fokus på just gruppen mobbade homosexuella ungdomar.

De unga HBT-personernas fortfarande ganska svåra situation tas upp i boken Komma ut, berättelser från garderoben av Anders Öhrman, chefredaktör för tidningen QX. Flera av de äldre intervjuade berättar om den totala frånvaron av homosexuella förebilder under deras ungdom - något som unga idag inte borde behöva uppleva. Ändå visar det sig genomgående vilket trauma komma-ut-processen har varit för de flesta, även i dagens generation. Särskilt svårt är det naturligtvis för ungdomar från andra kulturer än traditionellt svenska, där föräldrarna lever kvar med nedärvda homofoba moralbegrepp, eller för barn i strängt religiösa familjer. Den I9-årige 
Robert vars föräldrar kom som flyktingar från Libanon berättade när han var ı6 år för sin mamma att han var bög. Som resultat blev han utslängd hemifrån och fick utan pengar och arbete försöka sova hos vänner och på olika lokaler för hemlösa. Exemplet är inte unikt: många andra unga från invandrarfamiljer har berättat om samma öde. Ytterligare andra berättar om internaliserad homofobi: rädslan för att berätta för de närmaste, skräcken för att bli avvisad. Två mycket kända medieprofiler, Anders Öhrman själv och Roger Nordin, vågade inte möta sina föräldrar öga mot öga utan skrev ett brev resp. skickade ett mail; Roger drog för säkerhet skull därefter ut telefonjacket. Hoppfullt är visserligen att utgången för de flesta intervjuade blev lycklig, men intervjuboken är ändå mycket viktig för att förstå hur svårt det kan vara än idag att vara ung och inse att ens känslor främst är riktade mot det egna könet. 